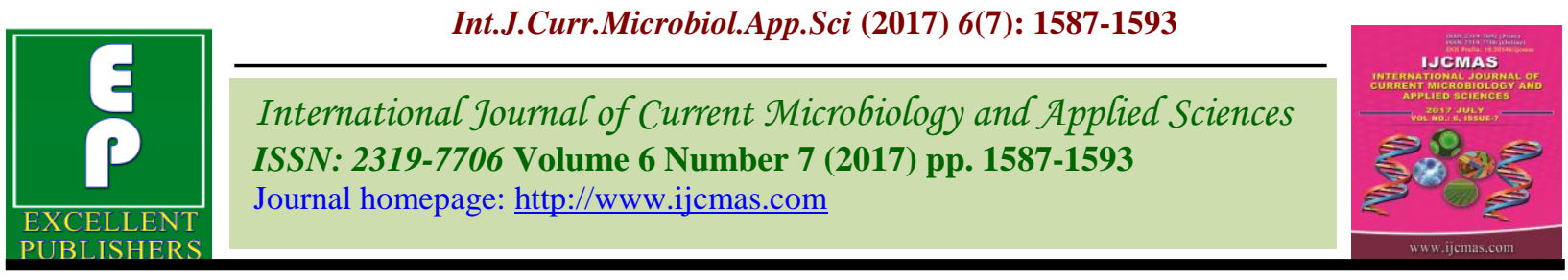

Original Research Article

https://doi.org/10.20546/ijcmas.2017.607.191

\title{
Heterosis Studies in Cow pea (Vigna unguiculata (L.) Walp.)
}

\author{
D.M. Raut*, A.B. Tamnar, S.V Burungale and P.L. Badhe \\ Department of Agricultural Botany, College of Agriculture, Dhule-424 001, India \\ *Corresponding author
}

\begin{abstract}
A B S T R A C T
The present investigation entitled "Diallel Analysis in Cowpea (Vigna unguiculata

Keywords

Cowpea,

Heterosis

and Yield

component.

Article Info

Accepted:

19 June 2017

Available Online:

10 July 2017

(L.) Walp.)" was conducted during kharif, 2013.Seven diverse cowpea parents were selected and crossed in half diallel fashion in order to determine heterosis to identify promising hybrids for eleven traits including yield and its components. The maximum beneficial heterosis over mid parent was found for seed yield per plant $(103.59 \%)$, the highest significant heterosis over better parents was recorded for seed yield per plant $(58.57 \%)$. Considering the per se performance and magnitude of heterosis best performing hybrid GC-3 x HC-08-02 produced 15.60 $\mathrm{g}$ seed yield per plant, exhibited significantly maximum beneficial heterosis over mid parent $(103.59 \%)$ for the trait seed yield per plant. It is evident from present investigation that the hybrid combinations viz., GC-3 x HC-08-02, GC-06-01 x JOB-129, HC-08-02 x PGCP-1 and GC-3 x CP-105 exhibited the high per se performance, for heterobeltiosis for seed yield per plant.
\end{abstract}

\section{Introduction}

Cowpea (Vigna unguiculata (L.) Walp.) is called as poor man's food or vegetable meat due to high amount of protein in grain with better biological value on dry weight basis. Cowpea grain contains about $24.8 \%$ protein, $1.9 \%$ fat and $63.6 \%$ carbohydrates and is rich source of calcium and iron (Davis et al., 2000). In the cultigens cowpea, four sub species have been identified, in which unguiculata, the grain types and sesquipedal is the yard long bean type were commonly cultivated. The most encountered problem with cultivation of yard long bean or vegetable type is providing space and support for its vigorous viny growth habit (Valarmathi et al., 2007). In view of low input requirement and short maturity, its cultivation is quite

economic. As compared with crops particularly the cereals, cowpea offers better chances of crop production under adverse conditions of moisture stress and low fertility. Though India is leading producers of cowpea, however, its grain productivity is dismally low. In cowpea, research work for its improvement is very limited. Therefore, there is a great scope for its improvement and to increase the production by developing high yielding, disease and pest resistant, moisture stress resistant varieties (Ehlers and Hall, 1997) and improvement in nutritional value by increasing especially protein content. Among the different pulses grown, cowpea is grown in 12.5 million hectares with the productivity of $499 \mathrm{~kg}$ per ha in India 
(Anonymous, 2012). A breeder is confronted at the onset, by a rather complex problem normally the choice of parents for hybridization, because yield is a complex character, comprising a number of components each of which is a polygenically controlled and therefore, very susceptible to environmental fluctuations. The choice becomes still more difficult when the breeder has to select the parents from large germplasm and become often difficult to predict the parents on per se performance whether, any two parents would combine well to produce desirable genotypes. What is more important than characteristics of the individual parents is how well they combine with each other.

The information concerning breeding behavior of the parents is of fundamental important in plant breeding programme. For this application of biometric technique like diallel analysis was appeared to be the best useful tool for screening parents with rapid and reasonable degree of confidence which has practical utility in breeding programme aimed at genetic improvement of yield. The magnitude of heterosis provides a basis for genetic diversity and a guide to the choice of desirable parents for developing superior $F_{1}$ hybrids so as to exploit hybrid vigour, offering good possibilities of isolating transgressive segregants. Estimation of heterosis over better parent may be useful in identifying true heterotic cross combination and these crosses can be of immense practical value if they show superiority over best variety of area. Heterosis breeding has proved to be a potential method of increasing yield in most of the self fertilized crops dominance gene effects and higher gca effects indicate a greater role of additive gene effects controlling these characters. But both the gca and sca values are not significant then epistatic gene effects may play an important role in determining these characters. At present frequently diallel or line The knowledge on nature and magnitude of gene effects controlling inheritance of characters related to yield and its component traits will be helpful in formulating efficient breeding programme and enhancing the yield of the crops as well as finding out good general and specific combiners for yield and yield component traits. Therefore, the present investigation was planned to investigate the combining ability for yield and yield contributing trait.

\section{Materials and Methods}

There are seven genotypes namely GC-3, CPD-91, JOB-129, HC-08-02， CPD-91, PGCP-1, and GC-06-01 were selected based on the phenotypic diversity of the plants in respect of yield and yield components. Crosses were made between the seven parents following the scheme of $7 \times 7$ half diallel and 21 hybrids were obtained. All these crosses along with parents were grown together during Kharif2013 in a Randomized Block Design (RBD) with two replications at Agricultural Botany Section, College of Agriculture, Dhule, Maharashtra, India. The row of $4.5 \mathrm{~m}$. length and spacing of $0.45 \mathrm{~m}$ was adopted. Border rows were planted at the extreme of each replication. All the recommended cultural practices were carried out to raise a good crop.

Five competitive plants were selected randomly for recording the data on yield and its contributing traits viz., days to $50 \%$ flowering, days to maturity, plant height at maturity, number of branches per plant, number of pods per plant, pod length $(\mathrm{cm})$, number of seeds per plant, 100 seed weight $(\mathrm{g})$, seed yield per plant $(\mathrm{g})$, harvest index $(\%)$ and protein content (\%). The mean data of each plot was used for statistical analysis. Heterosis (expressed in percentage) was estimated over mid-parent, better parent and 
standard check for all characters as described by Rai (1979). Following formulae were used to calculate heterosis.

1) Heterosis over mid parent

Relative heterosis $(\%)=(\mathrm{F} 1-\mathrm{MP}) / \mathrm{MP}) \times 100$ $\mathrm{MP}=\mathrm{P}_{1}+\mathrm{P}_{2} / 2$

2) Heterosis over better parent

Heterobeltiosis $(\%)=(\mathrm{F} 1-\mathrm{BP}) / \mathrm{BP}) \times 100$

3) Heterosis over standard check

Standard heterosis $=(\mathrm{F} 1-\mathrm{SC}) / \mathrm{SC}) \times 100$

Where,

$\mathrm{F} 1=$ Mean value of $\mathrm{F} 1$ hybrid

$\mathrm{MP}=$ Mid Parent value $=\mathrm{P} 1+\mathrm{P} 2 / 2$

$\mathrm{P} 1=$ Mean performance of first parent

$\mathrm{P}_{2}=$ Mean performance of second parent

$\mathrm{BP}=$ Mean of better parent value

$\mathrm{SC}=$ Mean of the standard check

\section{Results and Discussion}

Analysis of variance revealed significant differences among the genotypes, parents and hybrids for all characters except pod length in parents (Table 1). This may obviously be attributed to the existence of sufficient variation among the parents and hybrids. Average performance of hybrids was different from that of the parent for all characters except pod length, as evident from the significant parent's vs. crosses source of variation for the characters studied. These results were in consonance with that of Meena et al., (2009) for seed yield per plant and other related traits. Mean sum of square due to parent, crosses and parent vs. crosses interaction were also significant for all the characters except pod length in parents and interaction. Therefore, heterosis effects were worked out for all the characters. The heterosis over mid parent ranged from -16.13 to $30.23 \%$. Six hybrids showed significant negative heterosis over mid parent, the hybrid HC-08-02 x PGCP-1 (-16.13\%) showed highest significant negative heterosis over mid parent. Heterobeltiosis ranged from 10.23 to $39.51 \%$ and only three hybrids exhibited significant negative heterosis over better parent, the hybrid, CPD-91 x CP-105 shows highest negative heterobeltiosis (10.23). The heterosis over standard check ranged from 0.00 to $48.10 \%$. None of the hybrid could able to express significantly negative heterosis over standard check. The heterosis over mid parent ranged from -11.61 to $10.07 \%$. Thirteen hybrids showed significantly negative heterosis over mid parent.

The hybrid, CPD-91 x HC-08-02 (-11.61\%) showed highest significant negative heterosis over mid parent. Heterobeltiosis ranged from -8.59 to $24.24 \%$. Only two hybrids, viz., GC$3 \times$ GC-06-01 (-8.59 \%) and GC-3 x PGCP-1 $(-7.38 \%)$ showed significant negative heterosis over better parent. The heterosis over standard check ranged from -7.80 to $26.24 \%$. Four hybrid recorded significant negative heterosis over standard check. Hybrid, CPD-91 x CP-015 (-7.80 \%) showed significant negative heterosis. The heterosis over mid parent for seed yield per plant was ranged from -6.85 to $103.59 \%$. Twelve hybrids showed significant positive heterosis over mid parent. The hybrid, GC-3 x HC-08$02(103.59 \%)$ showed maximum significant positive heterosis over mid parent which, was followed by GC-06-01 x JOB-129 (71.18\%) and HC-08-02 x PGCP-1 (69.93\%). The heterosis over better parent ranged from 15.18 to $58.57 \%$. Seven hybrids exhibited significant positive heterosis over better parent. The hybrids viz., GC-06-01 x JOB-129 (58.57\%), GC-3 x HC-08-02 (56.05\%) and HC-08-02 x PGCP-1 (49.29\%) were the highest amongst seven (Tables 2 and 3 ). 
Int.J.Curr.Microbiol.App.Sci (2017) 6(7): $\mathrm{xx}-\mathrm{xx}$

Table.1 Analysis of variance for seed yield and its different traits in cowpea

\begin{tabular}{|c|c|c|c|c|c|c|c|c|c|c|c|c|}
\hline & & M & $\mathbf{a}$ & n & $\mathbf{u}$ & m & $\mathbf{o}$ & & $\mathbf{S}$ & $\mathbf{u}$ & $\mathbf{r}$ & $\mathbf{s}$ \\
\hline Variation & d.f. & Dass to 50\% Flowering & Days to Maturity & Plant Height at Maturity & $\begin{array}{l}\text { No. of Branches } \\
\text { /Plant }\end{array}$ & No. of Pods/ Plant & Pod Length & No. of Seeds/Pod & 100 Seed Weight & Seed Yield/Plant & $\begin{array}{l}\text { Harvest } \\
\text { Index }\end{array}$ & $\begin{array}{l}\text { Protein } \\
\text { Contain }\end{array}$ \\
\hline Replications & 1 & 1.446 & 1.786 & 12.635 & 0.483 & 0.206 & 1.612 & 0.339 & 0.031 & 5.375 & 6.365 & 0.845 \\
\hline Treatments & 27 & $60.632 * *$ & $121.587 * *$ & $344.025^{* *}$ & $0.991 * *$ & $21.493 * *$ & $2.643^{* *}$ & $3.914 * *$ & $2.938 * *$ & $13.851 * *$ & $5.771 * *$ & $118.897 * *$ \\
\hline $\mathrm{Parents}$ & 6 & $62.333 * *$ & $190.643 * *$ & $581.913^{* *}$ & $1.190 * *$ & $26.025 * *$ & 1.073 & $1.617^{*}$ & $4.693 * *$ & $4.947 *$ & $4.298 * *$ & $230.834 * *$ \\
\hline Crosses & 20 & $59.745 * *$ & $100.431 * *$ & $287.018 * *$ & $0.889 * *$ & $18.997 * *$ & $3.149 * *$ & $4.553 * *$ & $2.459 * *$ & $13.124 * *$ & $4.831 * *$ & $89.631 * *$ \\
\hline Parent vs Crosses & 1 & $68.149 * *$ & $130.381 * *$ & $56.840 * *$ & $1.844 * *$ & $44.229 * *$ & 1.929 & $4.923 * *$ & $1.972 *$ & $81.831 * *$ & $33.411 * *$ & $32.595^{* *}$ \\
\hline $\mathrm{E} \quad \mathrm{r} r \quad \mathrm{o} r$ & 27 & 2.483 & 2.0008 & 4.299 & 0.112 & 4.067 & 0.619 & 0.600 & 0.424 & 1.474 & 1.101 & 0.591 \\
\hline
\end{tabular}

Significant at $5 \%$ level. $\quad$ ** $\quad$ Significant at $1 \%$ level. 


\section{Int.J.Curr.Microbiol.App.Sci (2017) 6(7): xx-xx}

Table.2 Heterosis for seed yield per plant in cowpea

\begin{tabular}{|c|c|c|c|c|}
\hline \multirow{2}{*}{$\begin{array}{l}\text { Sr. } \\
\text { No. }\end{array}$} & \multirow[t]{2}{*}{ Hybrids } & \multicolumn{3}{|c|}{$\%$ heterosis over } \\
\hline & & M.P & B.P. & S.C. \\
\hline 1 & GC-3 X CPD-91 & $50.38 * *$ & $37.00 * *$ & $-16.89 *$ \\
\hline 2 & GC-3 X HC-08-02 & $103.59 * *$ & $56.05 * *$ & -5.34 \\
\hline 3 & GC-3 X PGCP-1 & 16.08 & -1.10 & $-40.01 * *$ \\
\hline 4 & GC-3 X GC-06-01 & 13.90 & -0.85 & $-39.85 * *$ \\
\hline 5 & GC-3 X JOB-129 & $63.00 * *$ & $32.60 *$ & $-19.56^{*}$ \\
\hline 6 & GC-3 X CP-105 & $58.34 * *$ & $48.80 * *$ & -9.74 \\
\hline 7 & CPD-91 X HC-08-02 & $43.17 * *$ & 18.00 & $-41.16 * *$ \\
\hline 8 & CPD-91 X PGCP-1 & $37.22 *$ & 27.37 & $-36.49 * *$ \\
\hline 9 & CPD-91 X GC-06-01 & 20.60 & 14.66 & $-42.83 * *$ \\
\hline 10 & CPD-91 X JOB-129 & 15.39 & 1.70 & $-49.29 * *$ \\
\hline 11 & CPD-91 X CP-105 & 2.67 & -0.68 & $-47.01 * *$ \\
\hline 12 & HC-08-02 X PGCP-1 & $69.93 * *$ & $49.29 * *$ & $-36.25 * *$ \\
\hline 13 & HC-08-02 X GC-06-01 & -1.33 & -15.18 & $-61.87 * *$ \\
\hline 14 & HC-08-02 X JOB-129 & 10.78 & 2.47 & $-61.03 * *$ \\
\hline 15 & HC-08-02 X CP-105 & $31.75 *$ & 5.80 & $-43.55 * *$ \\
\hline 16 & PGCP-1 X GC-06-01 & -6.85 & -9.18 & -59.18 \\
\hline 17 & PGCP-1 X JOB-129 & 31.93 & 24.72 & $-46.74 * *$ \\
\hline 18 & PGCP-1 X CP-105 & $33.25 *$ & 19.95 & $-36.00 * *$ \\
\hline 19 & GC-06-01 X JOB-129 & $71.18 * *$ & $58.57 * *$ & $-28.72 * *$ \\
\hline 20 & GC-06-01 X CP-105 & $39.15 * *$ & 28.20 & $-31.60 * *$ \\
\hline 21 & JOB-129 X CP-105 & $62.89 * *$ & $39.51 * *$ & $-25.57 *$ \\
\hline
\end{tabular}

Significant at $5 \%$ level. $\quad$ ** Significant at $1 \%$ level. 


\section{Int.J.Curr.Microbiol.App.Sci (2017) 6(7): xx-xx}

Table.3 Hybrids showing maximum beneficial heterosis over mid parent, better parent and standard variety

\begin{tabular}{|c|c|c|c|c|c|c|c|}
\hline \multirow{2}{*}{$\begin{array}{l}\text { Sr. } \\
\text { No. }\end{array}$} & \multirow{2}{*}{ Character } & \multicolumn{2}{|c|}{ maximum beneficial heterosis over mid parent } & \multicolumn{2}{|c|}{ maximum beneficial heterosis over better parent } & \multicolumn{2}{|c|}{ maximum beneficial heterosis over standard check. } \\
\hline & & $\begin{array}{lllllll}\mathbf{H} & \mathbf{y} & \mathbf{b} & \mathbf{r} & \mathbf{i} & \mathbf{d} & \mathbf{s} \\
\end{array}$ & Heterosis (\%) & $\begin{array}{llllll}\mathbf{H} & \mathbf{y} & \mathbf{b} & \mathbf{r} & \mathbf{i} & \mathbf{d} \\
\end{array}$ & Heterosis $(\%)$ & $\begin{array}{lll}\mathbf{r} & \mathbf{i} & \mathbf{d} \\
\end{array}$ & Heterosis(\%) \\
\hline 1 & Days to $50 \%$ flowering & HC-08-02 x PGCP-1 & $-16 \cdot 13$ & CPD-91 $\times$ CP-105 & -10.23 & - & - \\
\hline 2 & 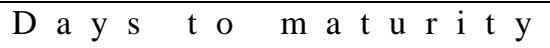 & CPD-91 x HC-08-02 & -111.61 & GC-3 -3 GC-06-01 & -8.59 & CPD-91 x CP-105 & -7.80 \\
\hline 3 & Plant height at maturity & JOB-129 x CP-105 & 37.52 & JOB-129 x CP-105 & . 9 & HC-08-02 x GC-06-01 & $\begin{array}{lllll} & 0 & . & 8 & 3\end{array}$ \\
\hline 4 & Number of branches per Plant & JOB-129 x CP-105 & $\begin{array}{lllll}3 & 3 & . & 3 & 3\end{array}$ & PGCP-1 x GC-06-01 & $\begin{array}{lllll}2 & 5 & . & 0 & 0\end{array}$ & $\mathrm{GC}-3 \times \mathrm{HC}-08-02$ & 14 \\
\hline 5 & Number of pods per plant & JOB-129 x CP-105 & $\begin{array}{lllll}5 & 1 & . & 3 & 8\end{array}$ & GC-06-01 x JOB-129 & 47.56 & - & - \\
\hline 6 & 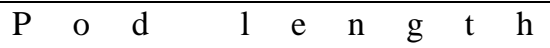 & G C - 3 $\times$ J O B - 129 & $\begin{array}{lllll}2 & 1 & . & 9 & 0\end{array}$ & $\mathrm{GC}-3 \times$ J O B - 129 & $\begin{array}{lllll}1 & 6 & . & 0 & 0\end{array}$ & HC-08-02 x PGCP-1 & 19. \\
\hline 7 & Number of seeds per plant & G C - 3 $\times$ J O B - 129 & $\begin{array}{lllll}2 & 5 & .9 & 2\end{array}$ & HC-08-02 x CP-105 & 200.65 & - & - \\
\hline 8 & $\begin{array}{lllllllllllll}1 & 0 & 0 & \text { s e e } & \text { w } & \text { w } & \text { i } & \text { h t }\end{array}$ & C P D - 91 & 266.52 & G C - $3 \quad x \quad$ C P D - 91 & $23 \quad .54$ & PGCP-1 1 J O B - 129 & $4 \quad 2 \quad .4 \quad 0$ \\
\hline 9 & Se ed yie ld per plant & GC-3 x HC-08-02 & $\begin{array}{llllll}1 & 0 & 3 & 5 & 9\end{array}$ & GC-06-01 x JOB-129 & $5 \quad 8 \quad . \quad 57$ & - & - \\
\hline 10 & 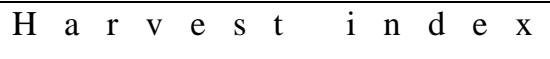 & GC-3 x HC-08-02 & $\begin{array}{lllll}5 & 7 & \cdot & 2 & 3\end{array}$ & CPD-91 x PGCP-1 & $\begin{array}{lllll}3 & 0 & . & 8 & 0\end{array}$ & $\mathrm{GC}-3 \times \mathrm{HC}-08-02$ & $\begin{array}{lllll}1 & 8 & \cdot & 3 & 8\end{array}$ \\
\hline 11 & 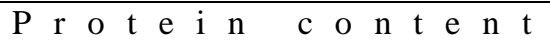 & PGCP-1 1 CP-105 & $\begin{array}{lllll}4 & 0 & . & 2 & 7 \\
\end{array}$ & CPD-91 x PGCP-1 & $\begin{array}{lllll} & 3 & . & 0 & 7\end{array}$ & PGCP-1 X CP-105 & $\begin{array}{lllll}3 & 4 & . & 0 & 3 \\
\end{array}$ \\
\hline
\end{tabular}


None of the hybrid could able to show significantly higher heterosis over the standard variety for seed yield per plant. weight, seed yield per plant and harvest index which suggested prime role of non-additive gene action.

\section{Acknowledgements}

Authors are grateful to the Mahatma PhuleKrishi Vidyapeeth, Rahuri (India) for providing the financial help to carry out this work and also to the Professor of Botany, College of Agriculture, Dhule for his keen interest and facilities provided for the present study.

\section{References}

Anonymous. 2012. FAO, FAOSTAT. http//www.faostat.fao.org.

Ayo-Vaughan, Monininuola Adefolake, Ariyo, Omolayo Johnson and Alake, Davis, D. W., Oelke, E.A., Oplinger, J., Doll J. D., Hansan, C.V. and Putnam,
D.H. 2000. Alternative field crops manual. pp. 1-9.

Ehlers, J.D. and Hall, A.E. 1997.Cowpea (Vigna unguiculata (L.) Walp.) Field Crop Res., 53: 187-204

Meena Ramesh, Pithia, M.S., Savaliya, J.J. and Pansuriya, A.G. 2009. Heterosis in vegetable cowpea (Vigna unguiculata (L) Walp.), Crop Improv., 36: 47-50.

Rai, B. 1979. Heterosis Breeding AgroBiological Publication, Delhi, pp. 183.

Ushakumari, R., Vairam, N., Anandakumar, R. and Malini, N. 2010. Studies on hybrid Vigour and combining ability for seed yield and contributing characters in cowpea (Vigna unguiculata). Electronic J. Plant Breeding, 1: 940-947.

Valarmathi, G., Surendran, C. and Muthiah, A.R. 2007. Studies on combining ability foryield and yield traits in inter subspecies of cowpea (Vigna unguiculata SSP. Unguiculata and Vigna unguiculata SSP. Sesquipedalis) Legume Res., 30: 173 - 179.

\section{How to cite this article:}

Raut, D.M., A.B. Tamnar, S.V. Burungale and Badhe, P.L. 2017. Heterosis Studies in Cow pea (Vigna unguiculata (L.) Walp.). Int.J.Curr.Microbiol.App.Sci. 6(7): 1587-1593. doi: https://doi.org/10.20546/ijcmas.2017.607.191 